\title{
Summary of the Research on the Transfer of Rural Surplus Labor Force
}

\author{
Xiaomei Pu1 ${ }^{*}$, Liujia Cheng2, Huimin Liu² \\ ${ }^{1}$ Research Center of Sichuan Old Revolutionary Areas Development, Sichuan University of Arts and Science, Dazhou, China \\ ${ }^{2}$ Dazhou Middle School, Dazhou, China \\ Email: ^47872614@qq.com
}

How to cite this paper: $\mathrm{Pu}, \mathrm{X} . \mathrm{M}$., Cheng, L.J. and Liu, H.M. (2019) Summary of the Research on the Transfer of Rural Surplus Labor Force. Open Access Library Journal, 6: e5416.

https://doi.org/10.4236/oalib.1105416

Received: April 22, 2019

Accepted: May 12, 2019

Published: May 15, 2019

Copyright () 2019 by author(s) and Open Access Library Inc.

This work is licensed under the Creative Commons Attribution International License (CC BY 4.0).

http://creativecommons.org/licenses/by/4.0/

\begin{abstract}
The transfer of rural surplus labor force is conducive to increasing farmers' income, improving farmers' quality, improving the comprehensive competitiveness of agriculture, and ultimately to the integration of urban and rural development. However, due to the low cultural quality and skill level of the transferred labor force, the stability of the transfer of rural surplus labor force in China is poor. To sort out the relevant theories of rural surplus labor at home and abroad can provide theoretical and methodological reference for the transfer of rural surplus labor in China, and provide ideas for solving the problem of rural surplus labor in China.
\end{abstract}

\section{Subject Areas}

Sociology

\section{Keywords}

Transfer of Rural Surplus Labor Force, Review, Theory

\section{Introduction}

The transfer of rural surplus labor force refers to the one-way flow process of the part of labor force that exceeds the demand of rural industry under the existing production conditions from agriculture to other local industries or industries in different places. But it does not include visiting of relatives and friends, tourism, curing diseases and other rural outgoing population, including periodic transfer which is people who work outside for more than six months and permanent transfer which means people who migrate to the place of transfer in the process. The transfer of rural surplus labor force is conducive to increasing farmers' income, improving farmers' quality, improving the comprehensive competitive- 
ness of agriculture, and ultimately conducive to the integration of urban and rural development. Since the reform and opening up, China has alleviated the problem of rural surplus labor transfer by developing township enterprises and promoting cross-regional migrant employment of labor force. According to statistics, in the third quarter of 2018, the number of rural surplus labor transfer in China was 181.35 million. However, due to the low cultural quality and skill level of the transferred labor force, the stability of the transfer of rural surplus labor force is poor. In order to further put forward effective countermeasures for the transfer of rural surplus labor force, it is necessary to carry out relevant research at home and abroad.

\section{Research Progress in Foreign Countries}

The research on the transfer of rural surplus labor force originated from foreign countries. Foreign scholars began to study the transfer of rural surplus labor force in the 1950s, and have made a lot of fruitful research results. Among them, dualistic economic structure theory and expected income theory have great influence.

\subsection{Dualistic Economic Structure Theory}

The classical theory of dualistic economic structure theory mainly includes Lewis model, Ranis-Fei model and Jorgenson model. The theory of dualistic economic structure was first put forward by William Arthur Lewis, an American economist, in 1954. In his view, there is a dual economic structure in developing countries, that is, the economy of developing countries is composed of the traditional rural agricultural sector and the modern industrial sector of cities. As the wages of the modern industrial sector in the city are higher than those of the traditional agricultural sector in the countryside and the capital accumulation and expansion of the modern industrial sector, the rural surplus labor continuously flow to the city. As long as the marginal productivity of industry is higher than that of agriculture, the transfer will continue until the rural surplus labor force is absorbed by the modern industrial sector. And he thinks the flow is barrier-free. After Lewis' model was put forward, it immediately aroused great repercussions in the academic circles. This research model has a great impact on economic development theory, labor transfer theory and so on. However, while affirming the rationality of the model, scholars also put forward the shortcomings of the model. The biggest disadvantage of this model is that it only emphasizes the expansion of the modern industrial sector, but neglects the development of the traditional agricultural sector. Secondly, the model does not recognize the existence of unemployment in the industrial sector, which is inconsistent with the actual situation in developing countries.

In 1964, American development economist Ranis Gustav and Chinese-American development economist Fei J.H. revised and expanded the Lewis model. They took the development of the agricultural sector and the improve- 
ment of agricultural productivity into consideration, which emphasized that the industrial and agricultural sectors must develop in a balanced way, and considered that the transfer of rural surplus labor force must go through three stages. Although the Ranis Gustav and Fei J.H. model takes into account the growth of agricultural productivity, it still does not take the unemployment in the industrial sector into account. It holds that as long as the wage level in the modern industrial sector is higher than that in the rural agricultural sector, the surplus rural labor force will continue to shift to the cities.

According to the analysis method of neoclassicism, D. W. Jorgenson, an American economist, put forward a dualistic economic model which is quite different from Lewis' model in his article Surplus Agricultural Labor and Dualistic Economic Development in 1967. The Jorgenson model holds that agricultural surplus is the prerequisite for the transfer of rural surplus labor, and the driving force of the transfer lies in the change of demand structure and consumption structure. He also believes that wages are rising with technological progress, which is obviously different from the fixed wages of Lewis et al. Jorgenson emphasized the development of agriculture and technological progress. However, this theory applies the hypothesis that the income elasticity of grain demand is zero and the Malthusian population theory, which is obviously inconsistent with the facts. At the same time, the theory also ignores the problem of urban unemployment.

\subsection{Expected Income Theory}

In 1970, the American economist M. P. Todaro and others put forward the theory of expected return in the article Population Flow, Unemployment and Development. Two-Sector Analysis. Different from the theory of dual economic structure, the theory considers that there is a large number of unemployment in the urban industrial sector, and holds that the expected income is the driving force for the transfer of rural surplus labor force. This explains the phenomenon that rural surplus labor force still transfers to the city when there is unemployment in the city. At the same time, the theory pays much attention to the development of the agricultural sector, which has important guiding significance for the economic development of our country. However, the theory simply summarizes the reasons for the transfer of rural surplus labor force as expected income, which is obviously inconsistent with the facts. And the cost of living of migrants in cities is neglected.

\subsection{Other Theories}

In addition to the above two famous representative theories, many foreign scholars have put forward relevant theories. For example, Stark's theory of relative poverty, Thodore W. Schultz's theory of human capital and E. Ravenstien's push-pull theory are also reasonable to explain the transfer of rural surplus labor. 


\section{Research Progress in China}

Since the mid-1980s, with the increasingly prominent phenomenon of rural surplus labor transfer in China, the theoretical circles have begun to explore and study the transfer of rural surplus labor. At present, domestic scholars have studied the transfer of rural surplus labor force from many aspects according to China's national conditions and economic structure characteristics, and around the phenomenon of rural surplus labor force transfer, which has promoted the healthy development of rural surplus labor force transfer. On the whole, the author believes that the research of domestic scholars mainly includes the following two aspects: one is the influencing factors of rural surplus labor transfer; the other is the specific mode and theory of rural surplus labor transfer.

\subsection{Factors Affecting the Transfer of Rural Labor Force}

In the aspect of influencing factors of rural surplus labor force, domestic scholars mainly focus on the influence of economic factors, personal characteristics factors and institutional factors on the decision-making of rural labor force transfer.

\subsubsection{Economic Factors}

Domestic scholars have systematically studied the impact of economic factors on the decision-making of rural labor transfer. The research results of Guoli Gao and the Migrant Workers Group (1995) reached the same conclusion. They believe that one of the main factors affecting the transfer of rural surplus labor force is the imbalance of regional economic development. The impact of regional economic development on the transfer of rural labor force can be divided into economic development level factors and economic structure factors.

\subsubsection{Personal Characteristics}

Domestic scholars have also made great achievements in the study of the impact of individual characteristics on rural labor force transfer decision-making, of which Yaohui Zhao and Nong Zhu have achieved the most remarkable results. They respectively studied the influence of education, gender, age and marital status on the transfer decision-making of rural surplus labor force. And they reached a common conclusion that marital status has a significant negative impact on the transfer decision-making of rural surplus labor force.

\subsubsection{Institutional Factors}

FangCai's research results are the most remarkable in the aspect of the influence of the research system on the decision-making of labor transfer. He divides the process of transferring rural surplus labor force into two stages: moving out of the countryside and settling down in the city. He believes that the traditional development strategy and the household registration system have a significant negative impact on the transfer decision-making of rural surplus labor force, and the ongoing reform has a significant positive impact on the transfer deci- 
sion-making of rural surplus labor force. He also believes that the role of reform will be more important than expected income and human capital at the present stage of our country.

\subsection{Specific Model of Rural Labor Transfer}

Chinese scholars have made great progress in the study of specific modes of rural labor transfer. The main modes include the industry-agriculture mode, local transfer mode, labor export mode, private economy mode, regional economic sustainable development mode and double-gradient cross-transfer mode.

\subsubsection{Industry-Agriculture Model}

Shimou Yao and others believe that with the continuous improvement of agricultural mechanization level, the rural surplus labor force will continue to increase. The main way to solve the transfer of rural surplus labor force is to develop the economic structure of industry-agriculture model and increase the population proportion of $\mathrm{t}[1]$.

\subsubsection{Local Transfer Model}

Lulu Cao and others believe that our country should vigorously develop township enterprises and absorb surplus rural labor through implementing the policy of giving up farming instead of leaving the hometown, entering the factory instead of entering the city [2].

\subsubsection{Labor Export Model}

Xiaofei Lv and others think that China, especially the populous provinces in China, should adopt the mode of labor export to solve the problem of rural surplus labor force [3].

\subsubsection{Private Economy Models}

HongquanLiaoand others consider that the development of private economy is conducive to the absorption of rural surplus labor force, so we should vigorously develop private economy to promote the transfer of surplus labor force [4].

\subsubsection{Regional Economic Sustainable Development Model}

Tao $\mathrm{Li}$ and others take for promoting the sustainable development of regional economy is the fundamental way to solve the transfer of rural surplus labor force [5].

\subsubsection{Double-Gradient Cross-Transfer Model}

Xiangzhi Kong and others deem that the transfer of rural surplus labor should be carried out according to the difference of labor gradient and regional intersection [6].

\section{Conclusion}

The above theory provides theoretical and methodological reference for the study of rural surplus labor transfer in China, and provides some ideas for solv- 
ing the problem of that. However, in recent years, with the proposal and implementation of the strategy of rural revitalization, new characteristics and opportunities have emerged in the transfer of rural surplus labor force. It is necessary to further explore the transfer of rural surplus labor force in the context of the new era.

\section{Conflicts of Interest}

The authors declare no conflicts of interest regarding the publication of this paper.

\section{References}

[1] Yao, S.M. and Wu, C.C. (1982) A Special Form of Urbanization of Rural Population in China-A Discussion on China's Agricultural-Industrial Population. Journal of Geography, No. 6, 155-161.

[2] Cao, L.L. (2013) Selection of Transfer Model of Rural Surplus Labor Force-Local Transfer Model. China Collective Economy, No. 20, 17-19.

[3] Lv, X.F. (2014) Present Situation and Countermeasures of Henan Province's Export of Foreign Labor Services. Chinese and Foreign Entrepreneurs, No. 31, 3-5.

[4] Liao, H.Q. (2014) Research on the Predicament of Peasants Engaged in Self-Management in Western Minority Areas-Enlightenment from Guizhou. Journal of Wuhan University of Technology Social Science Edition, No. 4, 587-590.

[5] Li, T. and Zhou, Z.P. (2019) Enlightenment of International Urbanization Development Model on New Urbanization Construction in Wanjiang Urban Belt. Journal of Chizhou University, No. 1, 56-59.

[6] Kong, X.Z. (2006) Realistic Choice of Labor Transfer in China-Double Gradient Cross Transfer Model. Sichuan Provincial Situation, No. 2, 34-35. 